\section{SOI: 1.1 TAS DOI: 10.15863 /TAS International Scientific Journal Theoretical \& Applied Science}

\author{
p-ISSN: 2308-4944 (print) e-ISSN: 2409-0085 (online) \\ Year: 2015 Issue: 04 Volume: 24 \\ Published: $30.04 .2015 \quad$ http://T-Science.org
}

Inna Aleksandrovna Serebryanik

Candidate of technical sciences, associate professor, Associate Professor of the Department of World economy Irkutsk National Research Technical University, Russia nasamolet@yandex.ru

SECTION 12. Geology. Anthropology.

Archaeology.

\title{
THE IRKUTSK CENTRE OF MICA PROCESSING: FORMATION AND DEVELOPMENT
}

Abstract: The article discusses the history of development of the Irkutsk centre of processing of mica. Presents the problems of the mica industry in the USSR. Analyzed potential strategic mining of mica 1930s of the XX century.

Key words: mica, Irkutsk, strategic material, industrialization, mica industry.

Language: Russian

Citation: Serebryanik IA (2015) THE IRKUTSK CENTRE OF MICA PROCESSING: FORMATION AND DEVELOPMENT. ISJ Theoretical \& Applied Science 04 (24): 44-47.

Soi: http://s-o-i.org/1.1/TAS*04(24)8 Doi: crossef http://dx.doi.org/10.15863/TAS.2015.04.24.8

\section{ИРКУТСКИЙ ЦЕНТР СЛЮДОПЕРЕРАБОТКИ: СТАНОВЛЕНИЕ И РАЗВИТИЕ}

Аннотация: В статье рассмотрена история становления Иркутского центра переработки слюды. Представлены проблемы слюдяной отрасли в СССР. Проанализирован стратегический потенциал добычи слюды 1930-х ге. ХХ века.

Ключевые слова: слюда, Иркутск, стратегический материал, индустриализация, слюдяная промышленность.

В истории горного дела России ни одна отрасль, пожалуй, не имеет таких глубоких корней, как слюдяной промысел. В данной статье поставлена цель - изучить историю слюдяного производства в городе Иркутске.

Слюдяной промысел зародился на Русском Севере на рубеже X-XI вв., а к середине XVIII века слюдяной промысел стал приходить в упадок. Резкое снижение слюдодобычи традиционно связывают с широким распространением стекла, которое к тому времени вытеснило слюду. Ленинский план ГОЭЛРО (20-е гг. ХХ в.) вернул слюде прежнюю популярность [10]. Только теперь она нашла новое применение - в качестве диэлектрика в электрических машинах и радиоаппаратуре.

В стране сложилась парадоксальная ситуация. Обладая огромными запасами слюды, СССР покупал ее за границей, например, в Германии. Германия же сама приобретала слюду у Индии и Америки, и соответственно, перепродавала ее по спекулятивным ценам. Импорт слюды в 1900-1904 гг. составил 75 тонн, 1905-1909 гг. - 153 тонны, в 1910-1913 гг. - 313 тонн [3; С.17]. То есть до революции промышленной добычи слюды в России не было. В годы гражданской войны ситуация принципиально не изменилась. В 1920-ее годы началось так называемое «первобытное копание» слюды с кайлом и свечой. Слюду добывали только с поверхности и переходили на другой участок.

Поскольку молодая советская республика нуждалась в слюде, необходимо было развивать слюдяную промышленность. Вместо примитивного ручного труда стали применять механическое бурение. Первая пятилетка - время рождения советской слюдяной промышленности. В этот период развернулись большие работы по разведке и добычи слюды. Уже в 1924 году началась ее добыча в Слюдянском районе, в 1927 году - в Мамско-Чуйском. В 1927 году на базе Института прикладной минералогии в Слюдянке был образован «Сибслюдтрест». С его созданием закончилась деятельность частных предпринимателей по добыче слюды. 17 сентября 1928 года по распоряжению Сибирского краевого Совета народного хозяйства «Сибслюдтрест» 
перевели в г. Иркутск. Позже он будет переименован в «Союзслюда».

Индустриализация требовала огромного количества минеральных ресурсов. Очень скоро добываемой слюды стало не хватать. В 1928 г. правительство приняло меры по активизации ее добычи. Если в 1927 году на Мамско-Чуйском месторождении добывали 7 тонн слюды, то к 1932 году добыча достигла 2216 тонн. К 1931 году добыча слюды Слюдянском месторождении достигла 3721 тонн [2; С.66]. Фактически с начала процесса добычи слюды в Иркутской области начинает развиваться промышленное производство, которое уже затрагивает не только интересы региона, но и российский и зарубежный рынки.

Изначально слюда с Мамских, Бирюнских и Слюдянских рудников обрабатывалась в мастерской Слюдянки. В 1929 году в г. Иркутске открылась мастерская по обработке слюды слюдорезка [6; С.130]. Она располагалась в старом купеческом амбаре напротив бывшего мелочного рынка. Слюдорезка ютилась в нескольких комнатах. Штат рабочих и служащих мастерской насчитывал 150 человек. Труд был преимущественно неквалифицированным. В газете «Власть труда» от 25 января 1930 года (раздел Биржа труда) видим объявление о приеме на работу в слюдорезку в том числе демобилизованных красноармейцев, не имеющих квалификации.

Работали в мастерской преимущественно женщины, которые вручную расщепляли слюду на тонкие (0,1-0,6 мм) пластинки и обыкновенными ножницами обрезали дефектные части. Не была решена проблема малой механизации. Разгрузка сырья из ящиков, подача навесок на рабочие места проводится преимущественно вручную [4; С.31]. Отсутствие механизации, неквалифицированные работники, частые простои делали производство крайне дорогим. Себестоимость продукции слюдорезки была на 85,5\% выше, чем по промфинплану [9; C.124].

По решению Окружной партийной конференции Иркутской слюдорезке было выделено 465 тыс.рублей для проведения строительных работ и реконструкции. Реконструкцию провело предприятие «Промстрой». Было реконструировано здание бывшей библиотеки на улице Свердлова.

Уже 1930 году мастерские были преобразованы в производственное предприятие - «Иркутскую слюдяную фабрику им. 8 марта». Директором Слюдфабрики был утвержден тов. Горбатов.
Перед «Сибслюдтрестом» была, по сути, поставлена задача поднять СССР с 4-го места по вывозу слюды в мире на 1-е. Предполагалось, что ресурсов Восточной Сибири для достижения этой цели вполне достаточно. Перед трестом ставились следующие задачи: повышать добычу слюды на рудниках, использовать новейшие методы в разведке, перейти к миканитовому производству, подготовить профессиональные кадры и другие. В августе 1930 г. «Сибслюдтрест» закончил и предоставил проект фабрики по переработке слюды и производству слюдяных изделий. Предполагалась, что на фабрике будет работать 10,5 тыс.рабочих. Планировалось открыть следующие подразделения: обрезка, щипка, штамповка и изготовление разных изделий из слюды (миканитов). Фабрика будет механизирована отечественным и зарубежным оборудованием. Из-за границы будет получен 18-ти этажный пресс, а с заводов СССР будут заказаны 150 приводных прессов, 300 микрометров, 50 механических приводных ножей, 5 молотковых мельниц, 4 грохота и 5 воздушных сепараторов. Предварительная оценка проекта 2 млн.400 тыс. рублей (по данным газеты «Власть труда», №185 (3197) от 17 августа 1930 г.).

Необходимо заметить, что с 1925 по 1966 годы на территории СССР были открыты 13 специализированных фабрик по переработке слюды. Среди них фабрики в Ленинграде, Петрозаводске, Нижнеудинске. Причем почти у каждой фабрики были цеха и участки, которые находились, как на близких, так и отдаленных территориях. Иркутской слюдфабрике суждено будет стать самой крупной и самой оснащенной в СССР. Она была предназначена для обработки наиболее качественной слюды - мамско-чуйской (мусковит).

Основной задачей муковитовых фабрик было максимальное извлечение высокосортной слюды - телевизионной, конденсаторной, радиодетальной. Фабрика становится основным поставщиком электроизоляционной слюды в Советском союзе. Если в 1927-1928 гг. «Сибслюдтрест» добыл 1223,5 тонн слюды (82\% от общей добычи в СССР), то за период с 1929 г по 1930 г. - 3439,1 (86,7\%). При этом мощности все еще оставались недостаточными для выполнения плана по обработке слюды [8; C.125].

С 1932 года начинает работу филиал Иркутской слюдяной фабрики в Нижнеудинске. Изначально, это была мастерская со штатом в 30 работников, занятых щипкой уже не мусковита, как на Иркутской слюдфабрике, а флогопита Слюдянского месторождения. К концу года 
численность работников выросла более, чем в семь раз.

Развитие слюдяной промышленности имело стратегические значение для страны, и планы ее развития были поистине грандиозными. В 1932 году трестом «Союзслюда» была принята первая технологическая схема обработки слюды. Ее составили на основе практики отечественных и зарубежных предприятий без каких-либо специальных исследований. И, если раньше основные операции по переработке очищенной слюды проводились на предприятиях электротехнической промышленности, то после утверждения схемы, основную функцию переработки стали выполнять слюдфабрики. Так в 1933 году был утвержден проект строительства Иркутской слюдяной фабрики стоимостью 3 млн.200 тыс. рублей.

В этом же году был построен новый корпус для щипки слюды. В 1934-1940 гг. сданы корпуса для помола слюды, главный корпус и новая электростанция. Строительство, как правило, велось в условиях нехватки стройматериалов. Оборудование монтировалось одновременно с реконструкцией. Страна жила под постоянной угрозой вражеского нападения, и развитие промышленной базы часто шло форсировано, без должной подготовки кадров. Руководители некоторых промышленных предприятий, в том числе и Иркутской слюдяной фабрики мало занимались вопросами подготовки кадров, не использовали такие формы повышения профессионально-технического уровня рабочих, как индивидуально-бригадное ученичество, курсы целевого технического назначения, клубы технического прогресса, школы коммунистических методов труда.

Первая пятилетка принесла желанные для власти плоды. Ценой больших вложений и усилий стране удалось освободиться от импорта слюды из-за рубежа и удовлетворять потребности промышленности только из собственных источников. За период 1931-1934 гг. в развитие слюдяной промышленности было вложено 18 млн. 634 тыс. руб. К концу первой пятилетки (1932 г.), СССР занимал одно из первых мест в мире по добыче слюды.

Иркутская область стала центром слюдяной промышленности. Во-первых, тут сосредоточились две крупнейшие в СССР слюдяные фабрики - Иркутская и Нижнеудинская. Во-вторых, здесь же располагались два больших горнодобывающих предприятия - Слюдянское и Мамское. Все эти предприятия составляли большую часть слюдяной промышленности СССР. В Иркутске также располагался научный центр по изучению слюды.

В 1935 г. на Иркутской слюдяной фабрике впервые в слюдяной промышленности вводится производство полуочищенной слюды и ее щипка. В 1936 г. было освоено производство новых видов продукции, такой как электроотражатели, авиашайбы, конденсаторная слюда и другие.

К 1938 году на Иркутской слюдфабрике трудилось около 2000 рабочих и служащих, валовая продукция составляла 11717 тыс. рублей.

В 60-х годах начинает широко внедряться автоматика. Новейшее оборудование позволяет фабрике увеличивать выпуск радиодеталей и конденсаторной слюды. За 1967-1971 гг. производство радиодеталей возросло на 28\%, конденсаторной слюды - на 26\%. В производстве начинают использовать вторичное сырье. Это снизило себестоимость продукции и увеличило объем производства на 7,8\%.

Таким образом, к середине XX в. Иркутская область стала флагманом добычи и переработки слюды в СССР. Самым крупным центром переработки ценного минерала являлась «Иркутская слюдяная фабрика им. 8 марта». Сегодня этот символ советской эпохи канул в лету. Однако сегодня можно говорить о возрождении спроса на слюду, в таких отраслях, как автомобилестроение (резинотехнические изделия, лакокрасочные материалы), строительство (отделочные материалы) и многие другие.

\section{References:}

1. (2015) Arhiv gazety Vlast' truda: Available: http://ellib.library.isu.ru/vlast_truda/index.php (Accessed: 06.04.2015).

2. Volobuev GT (2009) Centr sljudjanogo proizvodstva v Krasnojarskom krae. Sibirskij subjetnos: kul'tura, tradicii, mental'nost': materialy V Vserossijskoj nauchnoprakticheskoj Internet-konferencii na sajte sibsubethnos.narod.ru, 15 janvarja - 15 maja 2009 goda / Federal. agentstvo po obrazovaniju, GOU VPO "Krasnojar. gos. ped. un-t im. V. P. 
Astaf'eva". - Krasnojarsk : KGPU im. V. P. Astaf'eva, 2009. -pp. 65-78.

3. (2000) Gody i ljudi sljudjanoj Mamy: (Istorija Mamsko-Chujskoj jekspedicii) / M.I. Verhoturov [i dr.]; Irkut. gos. tehn. un-t. Irkutsk: Izd-vo IrGTU, 2000. - 324 p.

4. Dubenskij AM, Leonov CB, Bajnblat JS (1985) Obogashhenie listovyh sljud, Irkutsk: Izd-vo Irkut.un-ta, 1985. - $184 \mathrm{p}$.

5. Dubovik MM, Libman JP (1966) Dve zhizni chudesnogo kamnja: Iz istorii sljudjanogo promysla v Rossii. - Moscow: Nedra, 1966. $-188 \mathrm{p}$.
6. Dulov AV (1990) Pamjatniki istorii i kul'tury Priangar'ja. - Bimkom, 1990. - 288 p.

7. (1928) Pervyj Sibirskij kraevoj nauchnoissledovatel'skij sezd: doklady sekcii «Nedra». T. II. Novosibirsk, 1928.

8. Petrov VP (1978) 'Rasskazy o treh neobychnyh mineralah' - Moscow: Nedra, 1978 - pp.176

9. Prjanishev BG (2001) Irkutskaja sljudjanaja fabrika V 1930-h gg. Vestnik Tomskogo gosudarstvennogo universiteta - №2(14) 2001. -pp.124-126.

10. Jemsli D (1993) Jelementy.- Moscow: Mir., 1993, $256 \mathrm{p}$. 